Available online at www.sciencescholar.us

Vol. 6 No. 1, April 2022, pages: 357-365

e-ISSN: 2550-696X, p-ISSN: 2550-6978

https://doi.org/10.53730/ijhs.v6n1.4440

\title{
Art Education on Big Data and Digital Platforms Base of Higher Education Institutions
}

\author{
CrossMark \\ Kseniia Prykhodko a, Olena Khil b, Olena Pobirchenko ${ }^{c}$, Oksana Umrixina $^{d}$, Vera Kalabska ${ }^{\mathrm{e}}$ \\ Olha Bobyr ${ }^{\mathrm{f}}$
}

Manuscript submitted: 26 September 2021, Manuscript revised: 9 December 2021, Accepted for publication: 21 January 2022

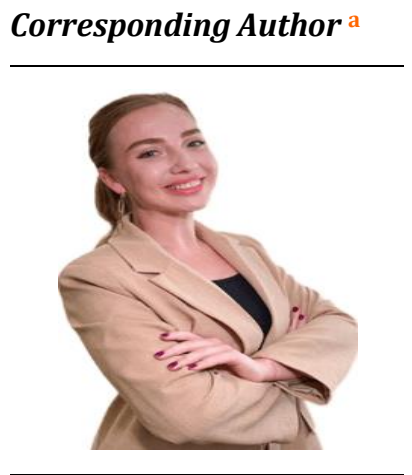

Keywords

academic analytics; art education; distance education; education market; education program; educational process; educational service; online learning;

\begin{abstract}
The study aimed to identify Big Data components and the role of the digital platform used for art education. In addition, the aim can be considered a definition of participants' role in the educational process in a broad application of Big Data and digital platforms. In conducting the research, a comprehensive approach was actively used, as well as descriptive methods, qualitative and quantitative ways of monitoring. We used questionnaires to get the necessary information, studied the essential literary sources, collected and analyzed data, and summarized the results. After summarizing the information obtained, it became clear that the Big Data use and digital platforms for art education allowed the transfer of the classical educational process to digital media and created the necessary environment for intellectualizing the educational process. In the future, it is worth considering and searching for options on how to get rid of the gaps in the use of information technology for art education. Relevant issues can be viewed as the problems of security, confidentiality, ethical component, compatibility, data storage, and processing problems, and the acute experienced personnel shortage.
\end{abstract}

International Journal of Health Sciences (C) 2022. This is an open access article under the CC BY-NC-ND license (https://creativecommons.org/licenses/by-nc-nd/4.0/).

\section{Contents}

Abstract

1 Introduction...

2 Materials and Methods.

\footnotetext{
a Kyiv National University of Culture and Arts, Kyiv, Ukraine

b Odessa National A. V. Nezhdanova Academy of Music, Odessa, Ukraine

c Pavlo Tychyna Uman State Pedagogical University, Uman, Ukraine

d Pavlo Tychyna Uman State Pedagogical University, Uman, Ukraine

e Pavlo Tychyna Uman State Pedagogical University, Uman, Ukraine

f Oles Honchar Dnipro National University, Dnipro, Ukraine
} 


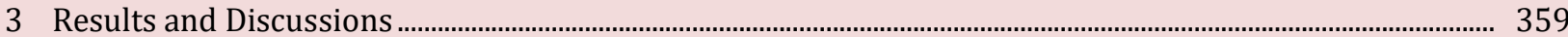

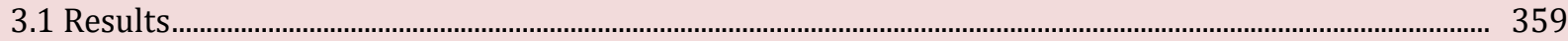

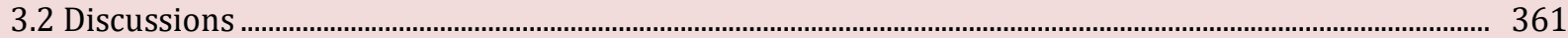

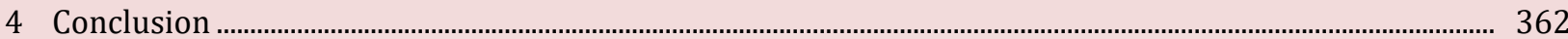

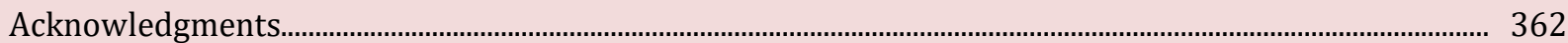

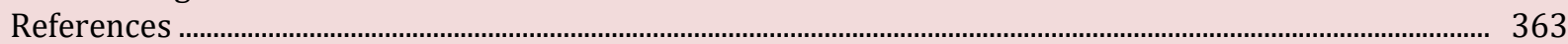

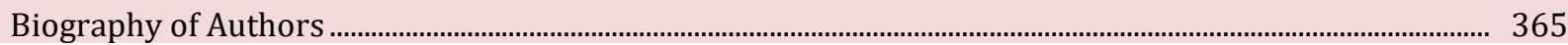

\section{Introduction}

The purpose is to perform a large number of tasks and to help improve the administration of higher education institutions. It also helps to monitor and improve the educational process, ensure the implementation of an innovative approach to forming assessment and teaching strategies, right decisions making, and position strengths in the education (Vieira et al., 2018). In addition, it is also possible to use Big Data to analyze the education market, identifying and predicting consumer characteristics. Moreover, the Big Data using and digital platforms can be called the work to increase the quality level of the educational process, quality level improvement the results of the educational process, as well as to ensure the training of professional staff (Yaqoob et al., 2016; Jagadish, 2015).

Thanks to the development of technology and the functionality of social networks, access to education has been greatly simplified (Dağ \& Geçer, 2009; Hung et al., 2010). The number of types of educational processes and methods of evaluation of the result has increased. Let us say more, to get quality educational materials, it is unnecessary to visit universities and classrooms themselves because they are available on the expanses of the Internet (Bamiah et al., 2018; Chakir et al., 2021). At the same time, there are exceptions, the first place among which probably belongs to art education, which even now involves the search for methods and forms of knowledge acquisition, demonstration of exhibition and concert potential, launching creative start-ups and practices. The focus should be on the possibilities of knowledge transfer through the online resources of Coursera, Show Academy, Udemy, which have developed and offer distance courses in many creative specialties for anyone who wants to learn and gain knowledge without age, social status, or geographical restrictions (Cope \& Kalantzis, 2016; Hesse et al., 2015; Cevallos et al., 2019). Thanks to this approach, higher education institutions have begun to introduce mixed forms of education - online distance learning and classical teaching using the full potential of information technology and communication (ICT) (Anirban, 2014; $\mathrm{Yu} \& \mathrm{Wu}, 2015)$. The specific and strong impact of the COVID-19 pandemic on different social spheres is summarized in the scientific works of Ksonzhyk et al. (2021), Barzylovych et al. (2020), Kliuchnyk et al. (2021). The purpose of this work is to investigate the Big Data and platforms role that help to improve the quality level of art education and to solve several problems:

- To establish the Big Data semantic and structural components that use for art education;

- Establish key distinctions of digital platforms that can be applied to art education.

\section{Literature review}

The name Big Data has been in use since the 1990s and gained popularity after its use in scientific papers (Mashey, 1999; Osmanbegovic \& Suljic, 2012). This definition should be understood as vast amounts of information that require specialized software to manage, collect, administer, analyze, and process information over some time (Snijders et al., 2012; Li \& Zhai, 2018). In Big Data, all data come in structured, semistructured, and unstructured, with the latter being the most heavily researched (Margetts \& Sutcliffe, 2013), especially in university curricula. Digital platforms and level outcome the educational process focuses on several relevant issues: supervising learning by teaching and assessment techniques, which are elevated to the rank of an essential part of the functioning of HEIs (Drigas \& Leliopoulos, 2014; Manjarres et al., 2018). 


\section{Materials and Methods}

Paper is guided by description, processing, and definition of the stated research tasks. On the theoreticalscientific basis, the application of descriptive methods, which are required in all social research in art education, was envisaged; the study also involved qualitative and quantitative analysis methods, the induction and deduction methods were used. It is necessary because the study of platforms is also represented by the social element (Martyniv et al., 2021; Alamsyah et al., 2021). Contains some social assessments of the integration of information technology in art. A key tool called a questionnaire survey was used to obtain research data. Literature collection, information collection, and analysis were used at this stage, and the results were summarized (Kitchin, 2014; Kumar et al., 2014).

The research project combined some European art universities these higher education institutions surveyed the implementation of Big Data and digital media in the university's educational process (Din \& Paul, 2019). The study involved 124 students arts; 24 people university administrations employees (A3) and 20 people from the teaching staff (B2) of the higher education institutions described above. The information collection began in September 2020 (for one academic semester). Respondents agreed to become volunteer participants of the study on confidentiality and anonymity, which was done (Simanca et al., 2020).

\section{Results and Discussions}

\subsection{Results}

Big Data and digital platforms for art education make possible the realization of the principle of individuality in the educational process, and personalization reduces the complexity of the organization and teaching activities evaluation and control (Stes et al., 2010; González-Martínez et al., 2015). In addition, it represents an essential part of functioning. Characteristics Big Data can be graphically reflected in the following diagram:

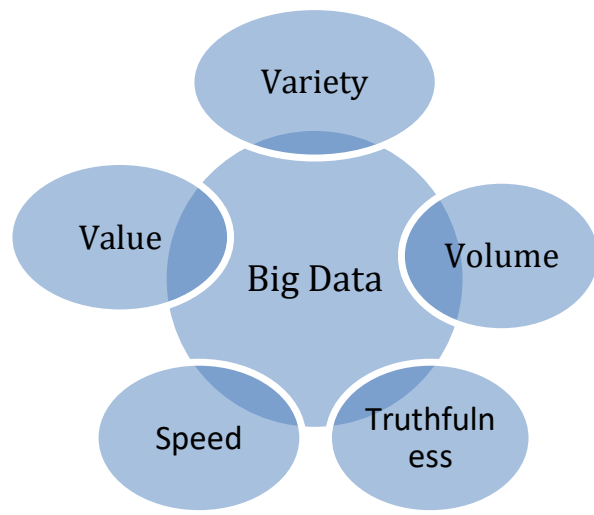

Figure 1. Basic big data characteristics

The "Volume" should be understood as the volume of information stored and generated. The importance of information determines the "Value" of the data found in Big Data. The type and characteristics of knowledge and the ability to process semi-structured data choose its "Variety". Big Data is defined by storing unstructured (diverse) data generated at high speed and in huge volumes. "Speed" - information needs to be generated and processed as quickly as possible to meet the educational process requirements as much as possible (Aldowah et al., 2019). "Truthfulness" of information depends on its quality and value. Big Data should have a considerable amount and be truthful and valuable in the analysis. The information value can only be achieved by analyzing and processing information in Big Data. The evaluation of other qualities can

Prykhodko, K., Khil, O., Pobirchenko, O., Umrixina, O., Kalabska, V., \& Bobyr, O. (2022). Art education on big data and digital platforms base of higher education institutions. International Journal of Health Sciences, 6(1), 357- 
measure it. The value of data can also be measured by analyzing the cost-effectiveness of data, which can only be achieved by analyzing large amounts of information (Madyatmadja et al., 2021; Schneider et al., 2019).

Table 1

Keyways using big data

\begin{tabular}{|c|c|c|}
\hline Realized projects & Application & Locations used in the project \\
\hline $\begin{array}{l}\text { Demand analysis and forecasting } \\
\text { for educational services, identifying } \\
\text { risks }\end{array}$ & Grading & USA Universities \\
\hline Online education implementation & Web.University, Eduson, Zillion & $\begin{array}{l}\text { Ukrainian and Japanese } \\
\text { universities }\end{array}$ \\
\hline $\begin{array}{l}\text { Visualization programs for } \\
\text { education }\end{array}$ & $\begin{array}{l}\text { Social media adapting } \\
\text { pedagogical practices (SNAPP) }\end{array}$ & $\begin{array}{l}\text { Australian universities, } \\
\text { educational institutions of Asia }\end{array}$ \\
\hline $\begin{array}{l}\text { Reporting processes reduction, } \\
\text { evaluation of educational } \\
\text { institution results and performance }\end{array}$ & $\begin{array}{l}\text { Data Mining, BDA, and Web } \\
\text { Dashboard }\end{array}$ & $\begin{array}{l}\text { Universities in Europe (Spain, } \\
\text { United Kingdom) }\end{array}$ \\
\hline $\begin{array}{l}\text { Minimization of reporting } \\
\text { processes, higher educational } \\
\text { institution performance evaluation }\end{array}$ & Degree Compass & $\begin{array}{l}\text { Universities in Europe } \\
\text { (Lithuania, Poland) }\end{array}$ \\
\hline
\end{tabular}

In modern education programs, the use of databases improves the cooperation of all parts of higher education. This greatly facilitates the management of such voluminous and complex institutions as modern higher education institutions. If we pay attention to the institutions of art education, it also simplifies the development directions analysis and forecasting, designing the development of creative directions (Diachenko et al., 2021).

Participating in the experiment have integrated blockchain using as an intelligent platform, which will facilitate and accelerate the mutual exchange of data, as well as common communications between faculty and students, faculty, and management. This, in turn, will help organize the educational process without intermediaries. Big Data and intelligent platforms are characterized by a wide range of uses for educational institutions, control, increase the competitiveness and reputation of higher education institutions, and are one of the fundamental factors in the success of higher education institutions.

Table 2

Use of intelligent platforms

\begin{tabular}{|c|c|c|}
\hline Goals & Appendix & Data to analyze \\
\hline $\begin{array}{l}\text { Knowledge verification } \\
\text { algorithms modeling }\end{array}$ & Knowledge and skills acquired & Typical errors \\
\hline Behavioral modeling & Motivation & $\begin{array}{l}\text { Work in the classroom, activities in the } \\
\text { learning management system (LMS), an e- } \\
\text { learning environment }\end{array}$ \\
\hline Learning satisfaction & Questionnaires, surveys. & $\begin{array}{l}\text { Assessment of the quality level of the } \\
\text { educational process, the work of } \\
\text { educational institutions, individual } \\
\text { teachers, managers, etc. }\end{array}$ \\
\hline Modeling curriculum & Topics, practical laboratory work & $\begin{array}{l}\text { Competencies, skills, habits problems } \\
\text { information }\end{array}$ \\
\hline $\begin{array}{l}\text { Instructional content } \\
\text { analysis }\end{array}$ & $\begin{array}{l}\text { Subjects and their sequence } \\
\text { within the curriculum, topics, and } \\
\text { their sequence within the course }\end{array}$ & Taxonomy of learning content \\
\hline $\begin{array}{l}\text { Customization and } \\
\text { personalization }\end{array}$ & $\begin{array}{l}\text { Learning experiences, creative } \\
\text { achievements of students and }\end{array}$ & Learning the history of students \\
\hline
\end{tabular}


teachers.

Each institution of higher education that took part in the study had already used hybrid intelligent educational platforms (Android; Prometheus) in their work. With the use of these platforms, the HEIs started their career:

- Fine Arts Academy, Gdańsk - since 2016;

- Arts Academy, Vilnius - since 2017;

- State Academy of Culture, Kharkiv - since 2020.

The Android platform offers ongoing support, feedback, and even graded diplomas. In addition, there are courses created by the best specialists and qualified staff of the industry "on-demand", for example, writing courses, which were developed based on Prometheus for Ukraine. The primary condition for developing a suitable distance learning. A specialized educational approach to increase the popularity and demand for Android and the development of new applications. After the trainees had passed it, and the results of the individual disciplines were credited (maximum - 30 credits), the company surveyed the quality of the platform.

Table 3

Assess the involvement of intelligent databases in higher education

\begin{tabular}{|c|c|c|c|}
\hline Questions & $\mathrm{C} 1$ & B2 & A3 \\
\hline Is there any real help for students? & $72 \%$ & $54 \%$ & $52 \%$ \\
\hline Can we call distance learning courses? & $68 \%$ & $23 \%$ & $30 \%$ \\
\hline Does the use of Big Data help predict the situation in the labor market? & $23 \%$ & $47 \%$ & $60 \%$ \\
\hline $\begin{array}{l}\text { Students can gain additional knowledge and skills, regardless of their geographic } \\
\text { location, and have a better chance of winning grant programs and competitions } \\
\text { through distance education? }\end{array}$ & $38 \%$ & $50 \%$ & $42 \%$ \\
\hline Does Big Data-based analytics impact finding better jobs in the job market? & $40 \%$ & $52 \%$ & $54 \%$ \\
\hline $\begin{array}{l}\text { Certifications obtained through innovative platforms affect future employment } \\
\text { opportunities }\end{array}$ & $58 \%$ & $43 \%$ & $38 \%$ \\
\hline Big Data skills help in reporting to management & $17 \%$ & $43 \%$ & $52 \%$ \\
\hline Innovative platforms provide information, helpful guidance, and practical skills & $71 \%$ & $39 \%$ & $41 \%$ \\
\hline With Big Data, monitoring educational outcomes and assessment has improved & $54 \%$ & $60 \%$ & $68 \%$ \\
\hline
\end{tabular}

The educational platforms' usage in the learning process will make it possible to increase the educational process's quality level, improve teamwork skills, and intensify intellectual activity. From this point of view, the educational process can be seen as a multilevel synthetic process. Speech scenarios, a cultural component, and simply the express ability of a personal opinion determine behavioral tactics, and conduct a dialogue are equally important.

The maximum support from students (72\%) was gained with the help of intelligent platforms, which allows expanding the range of knowledge; the question of where intelligent platforms can be used as a source of information received support by $71 \%$. The introduction of Big Data in the educational process will make possible the realization of the potential that creates in the sphere of art education consistency, consistency, focuses on practical results, and allows the completion of creative skills of all participants in the educational process.

\subsection{Discussion}

The rate at which information needed in arts education appears in Big Data is extremely low, although it is gaining weight in the educational process provides significantly more advantages in the education marketplace. Numerous research papers have described ways to implement educational platforms, and Big Data (West, 2012; Digital Education, 2017), developed and improved instructional manuals, management

Prykhodko, K., Khil, O., Pobirchenko, O., Umrixina, O., Kalabska, V., \& Bobyr, O. (2022). Art education on big data and digital platforms base of higher education institutions. International Journal of Health Sciences, 6(1), 357365. https://doi.org/10.53730/ijhs.v6n1.4440 
solutions, and catalogs based on this analysis. According to the study results, it can be argued that the adjustment and personalization of curricula and courses are possible based on assessments, assignments, and students' interest in further obtaining a specialty. It is possible to model the educational process results depending on the capabilities and resource base of higher education institutions (Sichkarenko, 2018; Valêncio et al., 2020; Williamson, 2016). Furthermore, Big Data can be used to analyze attendance, finding methods to increase student interest in attending institutions. Moreover, Big Data and learning platforms are used to improve experiment performance analysis, increase the accessibility of education to all comers, and assess the educational process's quality level and accountability (Wang, 2016; Widana et al., 2021). As the experiment shows, these capabilities have been approved by the participants of the educational process, especially the powers of educational services (65\% of approvals).

\section{Conclusion}

Big Data and intelligent platforms increase productivity and demand for art education. Furthermore, the systemic application of such technologies for education (teaching, guidance, reporting, public and practical activities) provides many new perspectives in improving and enhancing the effectiveness of educational activities. Clear evidence of this is the broad functionality available to Big Data and intelligent platforms in the educational process, the ability to implement distance learning, and, in general, the favorable opinion of the study participants about the use of innovative technologies. Among the positive factors in the application of intelligent platforms and Big Data in the educational process can be noted prediction of effectiveness, improvement, and systematization of courses, training programs, educational complexes; quick and truthful assessment of knowledge and skills of students; more accessible access to educational sites, assessment systems; improving the educational process quality; analysis of research work of pedagogical and scientific staff; visual analysis of the assessment of applicants.

In addition to the fact that implementing Big Data and digital platforms are characterized by enormous benefits, we cannot but talk about the problematic issues that are becoming an obstacle to their full integration. Consequently, it is necessary to continue working on the improvement of Big Data architecture, because before moving to the widespread implementation of educational institutions in the arts, it is essential to get rid of obsolete or modernize them, as well as to deal with information security, ethics, and privacy. In addition, it is necessary to train specialists to implement Big Data and intelligent platforms in the specifics of art education.

Acknowledgments

We are grateful to two anonymous reviewers for their valuable comments on the earlier version of this paper. 


\section{References}

Alamsyah, T., Marianthi, D., Hayati, W., \& Usrina, N. (2021). Drug user behavior about the development and rehabilitation process in Banda Aceh correctional institution. International Journal of Health \& Medical Sciences, 4(1), 88-94.

Aldowah, H., Al-Samarraie, H., \& Fauzy, W. M. (2019). Educational data mining and learning analytics for 21st century higher education: A review and synthesis. Telematics and Informatics, 37, 13-49. https://doi.org/10.1016/j.tele.2019.01.007

Anirban, S. (2014). Big data analytics in the education sector: needs, opportunities and challenges. International Journal of Research in Computer and Communication Technology, 3(11), 14251428.

Bamiah, S. N., Brohi, S. N., \& Rad, B. B. (2018). Big data technology in education: Advantages, implementations, and challenges. Journal of Engineering Science and Technology, 13, 229-241.

Barzylovych, A., Oliinyk, Y., Kostitska, I., Shakhman, N., \& Buryk, Z. (2020). Transformation of the Social and Medical Spheres under the Conditions of COVID-19. Systematic Reviews in Pharmacy, 11(11), 1328-1337.

Cevallos, M. A. S., Rosado, C. A. Z., \& Terán, O. V. T. (2019). The procedure used on diagnostic evaluation process. International Journal of Health \& Medical Sciences, 3(1), 1-10.

Chakir, A., Chergui, M., \& Andry, J. F. (2021). A decisional smart approach for the adoption of the IT green. Environment, Development and Sustainability, 23(6), 8857-8871.

Cope, B., \& Kalantzis, M. (2016). Big data comes to school: Implications for learning, assessment, and research. AERA Open, vol. 2(2), 1-19.

Dağ, F., \& Geçer, A. (2009). Relations between online learning and learning styles. Procedia-Social and Behavioral Sciences, 1(1), 862-871. https://doi.org/10.1016/j.sbspro.2009.01.155

Diachenko, A., Vusyk, H., Bielova, Y., Shurdenko, M., \& Titenko, O. (2021). The educational role in COVID-19 terms of ethnodesign graphic function in higher education practical activities. International Journal of Health Sciences, 5(3), 584-593. https://doi.org/10.53730/ijhs.v5n3.2540

Digital Education (2017). Beyond the classroom: a new digital education for young Australians in the 21st century.

Din, S., \& Paul, A. (2019). Retracted: Smart health monitoring and management system: toward autonomous wearable sensing for internet of things using big data analytics. https://doi.org/10.1016/j.future.2017.12.059

Drigas, A. S., \& Leliopoulos, P. (2014). The use of big data in education. International Journal of Computer Science Issues (IJCSI), 11(5), 58.

González-Martínez, J. A., Bote-Lorenzo, M. L., Gómez-Sánchez, E., \& Cano-Parra, R. (2015). Cloud computing and education: A state-of-the-art survey. Computers \& Education, 80, 132-151. https://doi.org/10.1016/j.compedu.2014.08.017

Hesse, B. W., Moser, R. P., \& Riley, W. T. (2015). From big data to knowledge in the social sciences. The Annals of the American Academy of Political and Social Science, 659(1), 16-32.

Hung, M. L., Chou, C., Chen, C. H., \& Own, Z. Y. (2010). Learner readiness for online learning: Scale development and student perceptions. Computers \& $\quad$ Education, 55(3), 1080-1090. https://doi.org/10.1016/j.compedu.2010.05.004

Jagadish, H. V. (2015). Big data and science: Myths and reality. Big Data Research,2(2), 49-52. https://doi.org/10.1016/j.bdr.2015.01.005

Kitchin, R. (2014). Big data, new epistemologies and paradigm shifts. Big Data Society, 1.

Kliuchnyk, A., Shebanin, V., Shebanina, O., Kormyshkin, Y., Rybachuk, V., \& Buryk, Z. (2021). Strategic Factors Quality Of Public Administration In Regional Development: The Experience Of Eu Countries. International Journal for Quality Research, 15(4), 1317.

Ksonzhyk, I., Lavrushchenko, Y., Marcin, O., Saienko, V., \& Buryk Z. (2021). Influence of Renewable Green Energy on the Economic Development of the EU States. Environment and Ecology Research, 9(5), 271-281.

Kumar, D., Kamesh, D. B. K., \& Syed, U. (2014). A study on Big Data and its importance. International Journal of Applied Engineering Research, 9(20), 7469-7479.

Li, Y., \& Zhai, X. (2018). Review and prospect of modern education using big data. Procedia Computer Science, 129, 341-347. https://doi.org/10.1016/j.procs.2018.03.085

Prykhodko, K., Khil, O., Pobirchenko, O., Umrixina, O., Kalabska, V., \& Bobyr, O. (2022). Art education on big data and digital platforms base of higher education institutions. International Journal of Health Sciences, 6(1), 357- 
Madyatmadja, E. D., Sembiring, D. J. M., Angin, S. M. B. P., Ferdy, D., \& Andry, J. F. (2021). Big Data in Educational Institutions using RapidMiner to Predict Learning Effectiveness. Journal of Computer Science, 17(4), 403-413.

Manjarres, A. V., Sandoval, L. G. M., \& Suárez, M. S. (2018). Data mining techniques applied in educational environments: Literature review. Digital Education Review, (33), 235-266.

Margetts, H., \& Sutcliffe, D. (2013). Addressing the policy challenges and opportunities of "Big data". Policy \& Internet, 5(2), 139-146.

Martyniv, L., Sokolova, A., Kurinna, S., Kopeliuk, O., Sediuk, I., \& Khomova, O. (2021). The modern problems and prospects of music formation and art education development during COVID-19. International Journal of Health Sciences, 5(3), 670-680. https://doi.org/10.53730/ijhs.v5n3.2936

Mashey, J. R. (1999). Big Data and the Next Wave of \{InfraStress\} Problems, Solutions, Opportunities. In 1999 USENIX Annual Technical Conference (USENIX ATC 99).

Osmanbegovic, E., \& Suljic, M. (2012). Data mining approach for predicting student performance. Economic Review: Journal of Economics and Business, 10(1), 3-12.

Schneider, K., Berens, J., \& Burghoff, J. (2019). Drohende Studienabbrüche durch Frühwarnsysteme erkennen: Welche Informationen sind relevant?. Zeitschrift für Erziehungswissenschaft, 22(5), 1121-1146.

Sichkarenko, K. (2018). Digital platforms: classification approaching and the role of economic development defining. Prychornomors' ki ekonomichni studiyi, 35, 28-32.

Simanca, F. A., Arteaga, I. H., Puin, M. E. U., Garrido, F. B., Paez, J. P., Méndez, J. C., \& Alvarez, A. (2020). Model for the collection and analysis of data from teachers and students supported by Academic Analytics. Procedia Computer Science, 177, 284-291. https://doi.org/10.1016/j.procs.2020.10.039

Snijders, C., Matzat, U., \& Reips, U. D. (2012). " Big Data": big gaps of knowledge in the field of internet science. International journal of internet science, $7(1), 1-5$.

Stes, A., Min-Leliveld, M., Gijbels, D., \& Van Petegem, P. (2010). The impact of instructional development in higher education: The state-of-the-art of the research. Educational research review, 5(1), 25-49. https://doi.org/10.1016/j.edurev.2009.07.001

Valêncio, C. R., Silva, L. M. M., Tenório, W., Zafalon, G. F. D., Colombini, A. C., \& Fortes, M. Z. (2020). Data warehouse design to support social media analysis in a big data environment. Journal of Computer Science, 126-136.

Vieira, C., Parsons, P., \& Byrd, V. (2018). Visual learning analytics of educational data: A systematic literature review and research agenda.Computers \& Education, 122, 119-135. https://doi.org/10.1016/j.compedu.2018.03.018

Wang, Y. (2016). Big opportunities and big concerns of big data in education. TechTrends, 60(4), 381-384.

West, D. M. (2012). Big data for education: Data mining, data analytics, and web dashboards. Governance studies at Brookings, 4(1), 1-10.

Widana, I.K., Sumetri, N.W., Sutapa, I.K., Suryasa, W. (2021). Anthropometric measures for better cardiovascular and musculoskeletal health. Computer Applications in Engineering Education, 29(3), 550561. https://doi.org/10.1002/cae.22202

Williamson, B. (2016). Digital education governance: data visualization, predictive analytics, and 'realtime'policy instruments. Journal of education policy, 31(2), 123-141.

Yaqoob, I., Chang, V., Gani, A., Mokhtar, S., Hashem, I. A. T., Ahmed, E., ... \& Khan, S. U. (2016). WITHDRAWN: Information fusion in social big data: Foundations, state-of-the-art, applications, challenges, and future research directions. https://doi.org/10.1016/j.ijinfomgt.2016.04.014

$\mathrm{Yu}, \mathrm{X}$., \& Wu, S. (2015). Typical applications of big data in education. In 2015 International Conference of Educational Innovation through Technology (EITT) (pp. 103-106). IEEE. 


\section{Biography of Authors}

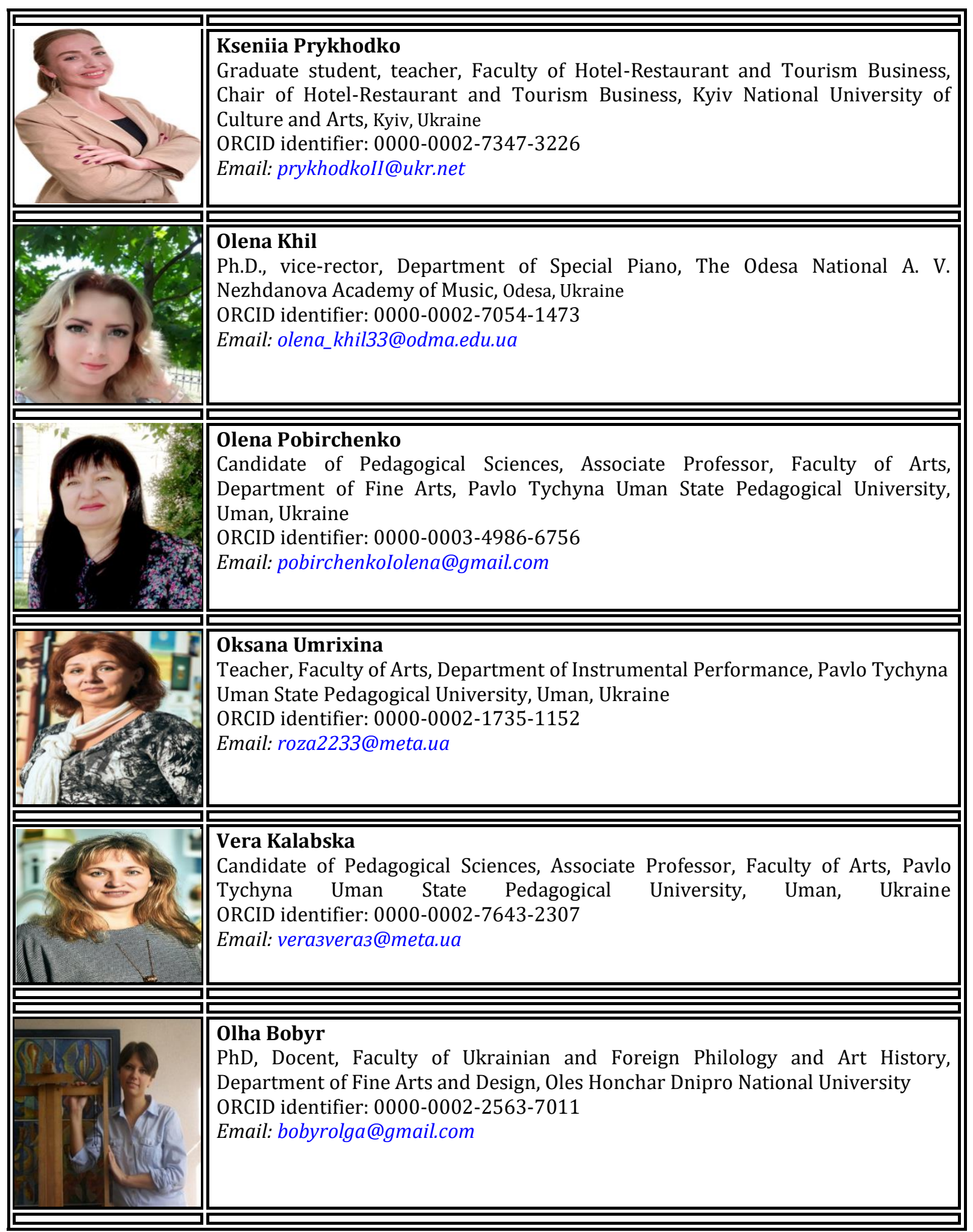

Prykhodko, K., Khil, O., Pobirchenko, O., Umrixina, O., Kalabska, V., \& Bobyr, O. (2022). Art education on big data and digital platforms base of higher education institutions. International Journal of Health Sciences, 6(1), 357- 